\title{
REVIEW
}

\section{THE MYTH OF UPWARD MOBILITY}

Death by a Thousand Cuts: The Fight over Taxing Inherited Wealth. By Michael J. Graetz and Ian Shapiro. Princeton and Oxford: Princeton University Press, 2005. Pp. $282+$ notes, glossary, index. \$29.95.

In our Hands: A Plan to Replace the Welfare State. By Charles Murray. Washington: American Enterprise Institute Press. 2006. Pp 127+app., notes. \$20.00.

\section{Richard Delgado*}

\section{INTRODUCTION}

The idea of upward mobility - that anyone who works hard, obeys the law, and saves his money can get ahead - is deeply engrained. From Horatio Alger stories to current Hollywood productions and TV programs, America pays homage to the tale of the hard working, upward striving youth who starts out poor but overcomes obstacles, opens a business, invents a machine, marries well, and ends up in a social class many stations higher than the one in which he or she began. ${ }^{1}$

Yet, studies have consistently shown that Americans enjoy much less upward (and more downward) mobility than is commonly believed. Most children of poor families remain so all their lives, and very few of those who start out in the lowest economic strata wind up at the top. Wealthy dynasties endure forever, while children born to middle-class parents rarely advance

* University Professor of Law and Derrick Bell Fellow, University of Pittsburgh School of Law. J.D., UC-Berkeley (1974).

1. See infra Part I ("Upward Striving in Myth and Narrative"). 
much beyond the bounds of that class any time during their lives. Despite its self image as an entrepreneurial, upward-striving society, the United States exhibits the least upward mobility of any Western industrialized society, including the ostensibly classless, highly taxed nations of Europe and Scandinavia. ${ }^{2}$

If the narrative of upward mobility is largely untrue, why does it exert such a hold on our imagination? We subscribe to it, perhaps, because, like all romantic stories, it corresponds to our deepest aspirations. We like to think of ourselves as an open, freedom-loving society where one rises or falls on the basis of one's merits and social contribution.

But the ideal also serves a number of less attractive purposes. It enables those of us who are comfortable to ignore the predicament of the poor. We can tell ourselves that, they too, could rise if they would only go to school, work hard, save their money, tend to their families, and stay out of trouble. ${ }^{3}$ It enables freemarket theorists to reason that the poor have no one but themselves to blame and that catering to them weakens their will to achieve. ${ }^{4}$ The myth gulls ordinary citizens like those who voted for repeal of the estate tax in the belief that they would die rich and wanted to pass their estates on to their children intact. ${ }^{5}$ And it discourages class consciousness among the working poor, many of whom harbor the unrealistic belief that they will one day be rich-win the lottery, be discovered by a Hollywood talent scout, cut a hit record, or make a fortune from an invention, song, or book - and so need not expend effort forging solidarity with other members of their class, whom they regard as losers. ${ }^{6}$ If one is somewhere only temporarily, why bother to get to know the locals?

Two recent books offer contrasting perspectives on mobility in our society. In Death by a Thousand Cuts: The Fight over Taxing Inherited Wealth, ${ }^{7}$ Michael Graetz and Ian Shapiro show how conservatives persuaded

2. On the precariousness of upward mobility, see infra Part III ("Upward Mobility in American Society"). On the worsening distribution of income and wealth, stagnant real wages, and the tenuousness of middle-class status, see Juliet Schor, As Public Goods Decay and Democracy Wanes, the Populace is Offered SUVs, Malls, and Debts, Boston Rev., Sept./Oct. 2005 [hereinafter Democracy Wanes].

3. See infra note 17 and accompanying text.

4. See infra notes 16, 23, 183, 186-90 and accompanying text.

5. See infra Part IIA (discussing Michael Graetz \& Ian Shapiro, Death by a Thousand Cuts: The Fight over Taxing Inherited Wealth (2005) [hereinafter Death by a Thousand Cuts]. See also Death By a Thousand Cuts at 6-7, 118-20 (noting that may Americans expect, unrealistically, to die rich).

6. See text and notes 18-19, infra; Death by a Thousand Cuts, supra note 5, at 6-7, 118-20 (noting that many Americans expect to die rich).

7. See Death by a Thousand Cuts, supra note 5. 
most of the American public to repeal the nearly 100-year-old estate tax in 2001. Enacted with broad bipartisan support, the repeal is scheduled to take effect a decade after its passage and came about as a result of a years-long grassroots campaign by right-wing and libertarian think tanks. Its backers billed it as a populist effort to promote the work ethic and American dream. In reality, abolition of the tax will benefit only a handful of very wealthy individuals and be a step toward eliminating progressive taxation, protecting vestiges of aristocratic privilege, and shrinking the role of government. Graetz and Shapiro show how the repeal happened and argue that it will make America much more unequal than it is now.

Charles Murray's In our Hands: A Plan to Replace the Welfare State ${ }^{8}$ is a proposal to do away with more than a trillion dollars of welfare transfer programs at the federal, state, and local levels and substitute instead an annual cash grant to every adult. For Murray the welfare state induces dependency and strips life of meaning, consequences, and initiative. Providing everyone with an annual stipend to use as they wish avoids these risks while revitalizing the family, vocation, and community. It can make government smaller while strengthening institutions such as churches, families, and small businesses. ${ }^{9}$

These two books, one by a pair of progressive scholars, the other by the conservative author of The Bell Curve and Losing Ground, represent diametrically opposite approaches to the politics of social justice. One argues for more government participation, the other for less. One demarcates a large role for the state in redistributing wealth, the other for a much smaller one. One corresponds, roughly, to Democratic ambitions and harkens back to the New Deal, Brown v. Board of Education, ${ }^{10}$ the Great Society, and the Sixties. The other corresponds to Republican programs including federalism, judicial quietism, supply-side economics, original intent, and the Contract with America. Deciding which course is best for a country like ours is a vital task, with welfare policy and tax reform as key ingredients in that challenge.

As will be seen, right-leaning authors like Murray assume that our society is relatively open and that, with a little seed money, anyone who works hard can succeed. By contrast, liberals hold that immigrants, minorities, and children often need a helping hand so that they can reach their potential. And for them, a key way to fund vital programs is by means of a progressive income tax.

8. Charles Murray, In Our Hands: A Plan to Replace the Welfare State (2006).

9. See infra Part IIB (discussing Murray's book and plan in further detail).

10. 349 U.S. 294 (1954) 
This Essay begins by surveying the myth of upward mobility and the part it plays in popular culture. ${ }^{11}$ Next, it discusses the two books mentioned above, showing how they rest on contrasting views about human agency and the possibility of rapid social advance. ${ }^{12}$ It then reviews social science studies of the extent of social mobility in the United States and shows how the legal system has helped construct its own version of it. ${ }^{13}$ A brief conclusion proposes a new narrative of working-class solidarity to replace the myth of upward mobility.

\section{Upward Striving in Myth and NarRative}

Upward striving and social mobility are deeply inscribed in American folklore. From the first religious settlers, to historical figures such as Benjamin Franklin, Andrew Jackson, and Abraham Lincoln, to Fourth of July speeches, to treasured documents such as the Declaration of Independence, to the waves of immigrants who passed through Ellis Island, we celebrate the self-made individual who rose high through her own efforts. This American Dream, as well as the stock stories we tell to reassure ourselves that it is still alive, teach that if one works hard enough, one will advance steadily toward a life of greater security, affluence, and fulfillment. ${ }^{14}$

While the dream did ring true during certain periods of history, it has never been a reality for the entire population. Society excluded many groups from the opportunity to share in that dream, ${ }^{15}$ and, even today, the muchvaunted middle class has begun to stagnate and shrink. ${ }^{16}$ Most Americans are

11. See infra Part I.

12. See infra Part II

13. See infra Part III.

14. See, e.g., Robert B. Reich, Story Time, New Repub., Mar. 28 \& Apr. 4, 2005, at 16 (discussing, as one of four constitutive American narratives, or tales, that of the upward striving youth who overcomes obstacles and achieves success). See also Richard Delgado, Inequality from the Top: Applying an Ancient Prohibition to an Emerging Problem of Distributive Justice, 32 UCLA L. Rev. 100 (1984); DeATH BY A Thousand CuTs, supra note 5, at 8 (pointing out that the general public — as well as a few "robber barons" such as Andrew Carnegie - in the early twentieth century supported enactment of the estate tax out of dislike of an "economic aristocracy of self-perpetuating elites"); text and notes 26-27, 214-17 infra (noting that effortless advancement and "lifestyle" consumerism are now developing as surrogates for the real variety). For an indication that the Framers intended a society with no permanent aristocracy, see the antinobility clause, U.S. CONST. art. 1, 9, cl. 8, which forbids the federal government from granting hereditary titles.

15. For example, blacks, who were enslaved; Indians, who were removed from their ancestral homes and exterminated; and Japanese-Americans, who suffered internment during WW II.

16. See infra Part III ("Upward Mobility in American Society"). See also Paul Krugman, Losing Our Country, N.Y. Times, June 10, 2005, at A23 (middle-class status is increasingly insecure for most 
ignorant of how the myth of upward mobility enables the wealthy to justify favorable treatment for themselves and cutbacks for the rest. It also fuels rhetoric holding that it is not the responsibility of the government to maintain a social safety net, that any failures are our own fault and any rewards the products of our own individual efforts. ${ }^{17}$

Political scientist Jennifer Hochschild compiles data in her 1996 book, Facing Up to the American Dream ${ }^{18}$ that suggest that working-class black Americans believe in the myth of upward mobility with an intensity that baffles more affluent African Americans, who see it as an opiate that blinds their lower-achieving counterparts to structural barriers that prevent collective action. ${ }^{19}$ In similar fashion, historian Jim Cullen exposes how the American Dream has served to justify the extermination of Native Americans and the enslavement of Africans. ${ }^{20}$

Civics-class versions of American history include well-known figures who embody the self-made man motif. Even though a vast majority of recent presidents and politicians have come from wealthy backgrounds, we celebrate Andrew Jackson and Harry Truman, who did not, and Abraham Lincoln who studied by the light of an oil lamp on his way to a life in law and politics. Even transcendentalist Ralph Waldo Emerson believed that the simple

families) [hereinafter Krugman, Losing Our Country]; Louis Uchitelle, Were the Good Old Days That Good? Maybe Not, But the Standard of Living was Climbing Much Faster, N.Y. TimEs, July 3, 2005, at $\S 3$ (Sunday Business), at 1, 7 (describing deteriorating living standards, including life expectancy, public services, infant mortality, obesity, and job security for many Americans); Schor, Democracy Wanes, supra note 2 .

17. See Peter Edelman, Where Race Meets Class: The 21st Century Civil Rights Agenda, 12 Geo. J. Pov. L. \& PoL. 1, 3 (noting that "Two explanations for the ... disparities compete. One is the classic American explanation - 'it's their own fault. Horatio Alger's heroes made it, why didn't they?"') [hereinafter Edelman, Race Meets Class].

18. Jennifer L. Hochschild, Facing Up to the American Dream: Race, Class, and the Soul of the Nation 72-73 (1996); see also Jim Cullen, The American Dream: A Short History of an Idea that Shaped a Nation 6 (2003) [hereinafter Cullen, Dream].

19. Blacks overall enjoy some of the least upward mobility of any group, with even the achievement of middle-class status insecure. See Edelman, Race Meets Class, supra note 17, at 6 (noting that median income of young African-American families dropped 48\% between 1973 and 1990 and that "Things continued to get worse." Id.). Black families have, on average, little savings, see Melvin L. Oliver \& Thomas M. Shapiro, Black Wealth, White Wealth: A New Perspective on Racial Inequality (1995), so that many find themselves living from payday to payday, depending on two or more incomes to make ends meet, and maintaining high levels of credit card debt. A relative's arrest or loss of a single job in a two-earner family can send a family into a downward spiral from which it may never recover. When that downward spiral starts, pawnbrokers, loan sharks, and predatory lenders, ever present in minority neighborhoods, are quick to take advantage of the family's vulnerability.

20. See Cullen, Dream, supra note 18, at 40, 47-48, 57. 
application of effort could make one the master of one's fate. ${ }^{21}$ Of course, during much of our history, Native Americans, blacks, women, and most working class people were missing from the upward mobility mystique, and stories rarely celebrated their triumphs, particularly when they took the form of resistance to the governing order. ${ }^{22}$

Alongside our selectively-framed history has developed a popular literature celebrating upward mobility. Horatio Alger stories and tales such as that of Dick Whittington and His Cat focus on good and righteous people who work hard, embrace the Protestant ethic, and earn their just rewards. ${ }^{23}$ Many wealthy members of society play up this aspect of their histories, ignoring the parts that luck, a well-connected friend, or an inheritance played in their rise. In our time, Martha Stewart and Bill O'Reilly, wealthy TV figures and entertainers, have spotlighted their humble roots-embellished considerably — in an attempt to connect with their audiences and inspire others with their rags-to-riches stories. ${ }^{24}$

Even reality television shows reinforce the idea that ordinary people can achieve sudden wealth so long as they have the "right stuff." Shows such as "Survivor" and "American Idol" reward the hard-working and talented. In similar fashion, "The Apprentice" teaches that one does not need an impressive Ivy League education, or even any special training, to succeed in business; all one needs is a winning personality, confident demeanor, and the willingness to take chances. ${ }^{25}$ One may be struggling, behind on one's credit card payments, and with no idea of how to finance one's children's education or one's own retirement. But if one maintains a happy face, keeps the faith,

21. See Ralph Waldo Emerson, Self-Reliance (1841).

22. See, e.g., Juan Perea et al., Race and Races: Resources and Materials for a Diverse AMERICA (2000) (discussing the often-suppressed legal histories of four racial minority groups of color); Tom Ross, The Rhetoric of Poverty: Their Immorality, Our Helplessness, 79 Geo. L.J. 1499 (1991).

23. See, e.g., Horatio Alger, Ragged Dick and Mark, The Match Boy (Two Novels) (1962); Alan Howard, Dick WhitTington AND His CAT (1948) (telling the much-told tale of a poor farm boy from Gloucestershire who walked to London to seek his fortune and eventually became Lord Mayor of that city); Charles McGrath, In Fiction, A Long History of Fixation on the Social Gap, N.Y. Times, June 8, 2005, at B1 (discussing upward mobility in popular myth and fiction) [hereinafter McGrath, In Fiction].

Upward striving can take a dark turn. See, e.g., Theodore Dreiser, American Tragedy (1925), telling about an upward-striving main character who drowns his lower-class sweetheart and winds up in the electric chair. See also Curtis Sittenfeld, Prep (2005), describing a blue-collar child smoldering with class resentment at a fancy private school); Scott FitzGerald, The Great GatsBy (1923) (telling a similar story of greed-fueled upward striving).

24. See Frank Rich, When You Got It, Flaunt It, N.Y. Times, Nov. 23, 2003, at 1.

25. See Cullen, Dream, supra note 18 , at 177 ; McGrath, In Fiction, supra note 23, at E4 (describing role of reality TV in shaping the aspirations of middle-class viewers). 
and perseveres, one's ship will come in. ${ }^{26}$ For African Americans, Jet and Ebony magazines perform a similar function, covering the opulent living styles of black entertainers and executives who have made it big with photo spreads of their cars, hair stylists, mansions, and animal rugs. ${ }^{27}$

Another trend among reality television shows targets a timely anxiety: the middle class's fear of falling. Shows such as "Extreme Makeover: Home Edition" and "The Scholar" give away a house, a college scholarship, health care, or cosmetic surgery, all foundations of upward mobility. The recipients of these bounties come across as having faith, being positive, and as refusing to blame others for their predicament. Their hardships are the product of fate, not cutbacks in social programs or changes in national priorities. The solutions to their problems are entirely individual, private, and local; the programs scrupulously avoid mentioning any need for a national collective effort. They teach that if we live by the tenets of the Protestant ethic- - work hard, do not grumble, and pray-we will find our miracles, too. ${ }^{28}$ This reading of the American Dream reinforces the idea that upward mobility is entirely an individual effort and that neither the government should help us nor are the wealthy to be blamed for our failures.

It is not only popular culture and civics-class history that teach the myth of upward mobility. As we shall see, legislatures and courts play a part as well. ${ }^{29}$ First, however, let us examine two recent books dealing with upward mobility and the government's role in advancing it.

\section{Recent Books on Spending Policy and Upward Mobility}

Two recent books illustrate contrasting approaches to upward mobility and the state's role in safeguarding it. Michael Graetz and Ian Shapiro's Death by a Thousand Cuts: The Fight over Taxing Inherited Wealth ${ }^{30}$ tells the

26. Cullen, Dream, supra note 18, at 160 (noting that the reward comes instantaneously, not gradually through hard work); McGrath, In Fiction, supra note 23. See also James Poniewozik \& Jeanne McDowell, When You Wish Upon a Star, Time, June 13, 2005, at 48 [hereinafter Poniewozik \& McDowell, Star].

27. In these stories, the key to success is "lifestyle"- a cluster of attitudes and styles of consumption - not effort. This type of coverage, which only started to appear regularly in the Reagan years and is not limited to the black press, downplays effort and persistence in favor of talent and destiny. Entertainers, media stars, and sports figures appear to have moved naturally and with little effort into their starring roles. $C f$. CULLEN, DREAM, supra note 18, at 177. On the cruel trap of investing all of one's hopes in a career in sports, see Hoop Dreams (Front Line Features, 1994).

28. Poniewozik \& McDowell, Star, supra note 26, at 48.

29. See infra Part IV ("The Official Construction of Upward Mobility").

30. Cited in full supra note 5 . 
story of the recent repeal of the estate tax. Graetz and Shapiro show how conservative operatives played upon the public's fears of a "death tax" that would deprive them of the right to pass their estates on to their children when they died. ${ }^{31}$ Of course, the estate tax only targeted the wealthiest sector of the population. $^{32}$ But Republican boosters, abetted by some middle-class and African American confederates, succeeded in persuading a majority of Americans that the estate tax was unfair to persons like them, ${ }^{33}$ as well as immoral. $^{34}$

Charles Murray's In Our Hands: A Plan to Replace the Welfare State ${ }^{35}$ urges the abolition of over one trillion dollars of welfare transfer payments in favor of a ten-thousand-dollar-a-year grant to every American over the age of $21 .^{36}$ Both books are, in their way, excellent: Graetz and Shapiro's a careful and scholarly dissection of a long-building conservative campaign, Murray's an audacious plan to transform how this nation approaches social support of the needy.

\section{A. Michael Graetz and Ian Shapiro, Death by a Thousand Cuts: The Fight Over Taxing Inherited Wealth}

The estate tax is relatively simple in concept. As Graetz and Shapiro explain, when a very wealthy person dies in this country, his or her estate pays a portion of the value of its assets to the government before the remainder passes on to the children or other heirs. ${ }^{37}$ The tax is subject to a number of exemptions. If the estate passes to a spouse, no tax is owed until that person dies. ${ }^{38}$ The same is true if the person leaves money to a charity or sets up a charitable foundation. ${ }^{39}$ Until the enactment of the 2001 tax bill, only individuals with assets of more than $\$ 650,000$ or married couples with assets of more than $\$ 1.3$ million were subject to the tax. ${ }^{40}$

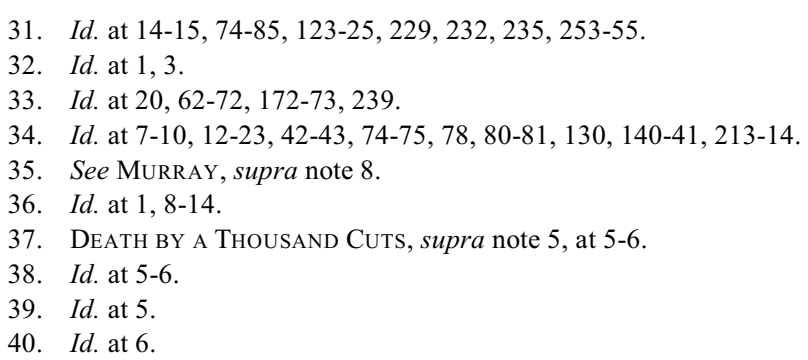


In 1999 , only 2.3 percent of all estates paid any estate tax at all, and the average size of those taxed was $\$ 2.5$ million. ${ }^{41}$ The average tax bill for those estates was $\$ 460,000$, or just under 19 percent. ${ }^{42}$ The amount of taxes that the government collected in this fashion was $\$ 24.4$ billion, an amount that would fund nearly one-half of the operating budget of the Department of Homeland Security or Department of Education, and twice the amount of annual Pell grants for higher education. ${ }^{43}$ Of the total proceeds, more than half came from the richest 7 percent of taxable estates, those valued at $\$ 5$ million or more, corresponding to the wealthiest 0.1 percent of our society. Nearly one-fourth of the total revenues, $\$ 5.7$ billion, came from 550 estates with $\$ 20$ million or more. And nearly two-thirds of the wealth taxed took the form of securities and other liquid assets, not family businesses or farms. ${ }^{44}$ The estate tax was the most progressive part of the American tax system because it rested on the idea that the wealthiest members of society, if they did not choose to leave their money to charity, should not be allowed to pass it all on untouched to their heirs. ${ }^{45}$

With these realities in mind, how did the pro-repeal forces manage to turn their campaign into a popular crusade? Graetz and Shapiro show how they successfully deployed a combination of strategies: Patiently gathering groups to the cause over time, preventing splits within the coalition, waging a singleissue campaign against the "death tax" in isolation from broader social concerns, and winning the moral-philosophical argument. ${ }^{46}$ They also raised a great deal of money from wealthy backers. ${ }^{47}$ The opposition's inability to marshal a timely response furthered the gathering momentum for repeal. ${ }^{48}$

The impetus for repeal came not from corporations or the halls of power but from the ground up. Central to the task was the work of a small number of true believers who devoted years of their lives to it, working patiently and behind the scenes. ${ }^{49}$ To prevail, they had to gain the support of nontraditional groups, such as first-generation minority business owners who might be

\footnotetext{
41. Id.

42. $I d$.

43. $I d$.

44. Id.

45. David Runciman, Tax Breaks for Rich Murderers, London Rev. Books, June 2005, at 27 [hereinafter Runciman, Rich Murderers].

46. Death By a Thousand Cuts, supra note 5, at 7-10, 12-23, 42-43, 74-75, 78, 80-81, 130.

47. Id. at 239-57.

48. Id. at 10 .

49. Id. at 9-31.
} 
vulnerable to the tax..$^{50}$ They also targeted the gay and lesbian community. Since gays and lesbians are not entitled to the "marital exemption," the tax comes due immediately upon the death of a partner and again at the time of the second partner's death. Thus gays were taxed twice, which newlysolicitous Republicans condemned as a form of discrimination. ${ }^{51}$ Ready to play the race card when it suited them, the conservative backers also promoted repeal among the black community on the ground that it penalized black businessmen who had successfully battled prejudice all their lives and hit them with a hefty tax just as they prepared to pass their hard-won earnings on to their children. ${ }^{52}$

The most formidable challenge for the repeal movement was the American middle class. ${ }^{53}$ Most of these citizens stood to gain little by repeal and to lose a great deal. ${ }^{54}$ Repealing the tax would relieve only the richest members of the public from the burden of paying taxes, while not benefiting the average citizen at all. Indeed, by reducing the tax dollars available for programs such as aid to college students, Homeland Security, Social Security, Medicare, medical and scientific research, and the national highway and park systems, repeal made life more difficult for a large majority of Americans.

How did the sponsors pull this off? They employed a number of strategies, some duplicitous, others perfectly legitimate. One was to separate the campaign against the estate tax from association with other causes, such as weakening environmental protections, gutting affirmative action, opposing gay marriage and child care, and increasing military spending, dear to most conservatives. ${ }^{55}$ By doing so, repeal advocates were able to bring many liberals into the fold and induce them to support a cause that would do little for most of them and further undermine the progressive agenda. ${ }^{56}$ Evidence of how successful these proponents were is that several members of the Congressional Black Caucus did, in fact, vote for repeal. ${ }^{57}$

The pro-repeal camp also managed to portray the estate tax as targeting not just the idle but the working rich, who became the poster children of the movement and garnered even more public support. ${ }^{58}$ By presenting horror

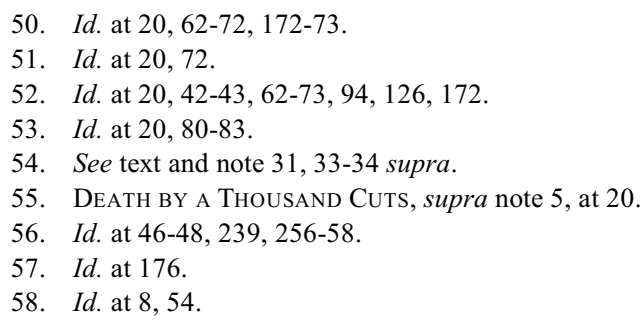


stories of small business owners or farmers faced with heavy penalties under the current scheme, proponents tapped into the public's Horatio Alger sympathies. ${ }^{59}$ If one started a business, the argument went, worked the long hours necessary to make it successful, earned money from and paid taxes on it, why should the government collect taxes from you a second time when you die ${ }^{60}$

Repeal boosters pointed out that the assets of these small businesses and farms were seldom liquid, but rather lay in the value of their equipment, crops, good will, and inventory, so that unless the decedent paid attention to estate planning and tax avoidance, enough liquid assets would not be on hand to cover the tax bill and the family would lose the farm or business. ${ }^{61}$ The story emerged of a spirit of entrepreneurship crushed when family farms and businesses could not be passed on to the heirs because of the greed and irrationality of the tax code. Boosters also argued that the forced sale of a family business hurt local economies, cost many jobs, and even injured the environment. ${ }^{62}$

The pro-repeal camp even managed to persuade a number of minority groups to sign on, by proclaiming that the "death tax" amounted to yet another form of discrimination. Only since the 1960's, they pointed out, have African Americans and other minorities begun to accumulate real wealth. ${ }^{63}$ Yet the "legacy killer" aimed to tax away the money that minorities worked so hard for, leaving them little to pass on to their heirs ${ }^{64}$ By contrast, white people, who have been able to accumulate wealth over generations, would be less severely affected. ${ }^{65}$ By 2001, the pro-repeal movement had not only gained the support of many African Americans but that of the National Association of Women Business Owners, the National Indian Business Association, the U.S. Hispanic Chamber of Commerce, and the U.S. Pan Asian American Chamber of Commerce. ${ }^{66}$

59. Id. at $8,43,51-54,57-61,63-66$.

60. See text and notes 65-73 infra, noting that this is not unusual; our system does it all the time.

61. Death By a Thousand Cuts, supra note 5, at 50-61.

62. Id. at $50-66$.

63. Id. at 172 .

64. Id. at 70-72, 172-76.

65. Id.; see also Charles Ogletree, All Deliberate Speed 195-96 (2005) (noting that, at a speech at Savannah State College, Clarence Thomas spoke approvingly of how a certain black business succeeded despite discrimination, how some blacks got ahead despite going to black schools and segregated libraries, and how they built homes in spite of segregated neighborhoods). Ogletree points out that Justice Thomas ignores how lack of venture capital, predatory lending, overcrowded schools, and other systemic hurdles prevent even more blacks from rising.

66. Death By a Thousand Cuts, supra note 5, at 72. 
Repeal proponents were not above embellishing the facts, for example by bringing Chester Thigpen, an African American owner of a tree farm in Mississippi, to testify before Congress. ${ }^{67}$ Thigpen's tale of woe turned out to be untrue; his son, Roy, later revealed that Thigpen's estate was not taxable because the value of its assets fell well below the threshold where the tax applies, and that his speech to Congress had been written by "some professors." through the 1990's contributed to a groundswell of popular support. One poll showed that 77 percent of the population believed-incorrectly-that the estate tax affected all Americans. ${ }^{69}$ More than one-third believed that they themselves would have to pay the tax, either because they misunderstood its nature or believed that they would somehow die rich. ${ }^{70}$ Some middle-class families with few savings thought that, by voting for repeal, they were helping their children get a good start in life. ${ }^{71}$

By deeming the inheritance tax the "death tax" and attaching it to specific families and individuals such as Chester Thigpen and his tree farm, prorepealers misled the public and preyed upon their greed. They also won the moral argument when they argued, falsely but with little opposition, that the tax only helps fancy lawyers, expensive tax accountants, and the insurance industry $^{72}$ and burdens families at exactly the wrong time: upon the death of a relative. ${ }^{73}$

They also won the moral argument by standing a commonsense argument on its head. Tax policies that exact heavy tolls on productive activity are not efficient; they deter that activity to some extent. But not taxing is unfair. One's heirs, usually children who have done nothing to generate the wealth and may be lazy louts, get to lead lives of leisure, while others, much more deserving, may go without. Progressive taxation tries to strike a balance, taxing different types of income with an eye to accomplishing a reasonable amount of social distribution without deterring production too drastically. That is the main reason why the estate tax lasted close to 100 years-it did

67. Id. at $62-66$.

68. Id. at 65-66.

69. Id. at 6 .

70. Id. at $6,7,119-20$.

71. Id. at 253 .

72. Id. at 7, 21-22.

73. See Runciman, Rich Murderers, supra note 45, noting how some advocates of repeal conjured up the image of the IRS hovering at the bedside, in the garments of the Grim Reaper, waiting for the dearlybeloved to die so that the agency can get its cut. 
relatively little to discourage wealth-generation, while providing concrete benefits for the rest of society. It was both efficient and fair. ${ }^{74}$

But the opposition turned this around. In addition to criticizing the estate tax as inefficient and prone to stifle wealth creation, they also attacked it as unfair. They renamed it the "death tax," with all the ghoulish overtones that the rechristened name evoked. They also characterized it as a burden on the person seeking to pass on his wealth toward the end of his life-like Chester Thigpen $^{75}$-rather than one placed on those who stood to inherit it, usually his children. And they portrayed the tax as unfair because it taxed income twice - once when you earn it, and later again when you die..$^{76}$ One supporter even likened it to the Holocaust, because it only targeted a small percentage of the population, and if you begin by looting one group, who knows where that will lead? $?^{77}$

Graetz and Shapiro examine the ever-widening circle of conservative think tanks, particularly the Heritage Foundation, that blurred the line between advocacy and public education by aligning with the forces of repeal. ${ }^{78}$ By isolating the estate tax from other issues, think tankers were able to present skewed polls suggesting that the tax was unpopular with a majority of Americans. These polls' results proved influential in persuading members of Congress that an irresistible tide was flowing against the estate tax. ${ }^{79}$

Against this formidable array of stories, anecdotes, and statistics, all backed by big money, opponents such as the Democratic Party, the insurance industry, labor unions, and charities entered the fray with too little, too late. ${ }^{80}$ The best the Democrats could do was a lethally complex alternative, the Qualified Family-Owned Business Interests (QFOBI) tax reform provision that exempted the first $\$ 1.2$ million of a business's assets. Overly complicated and strict, the plan proved a complete failure. ${ }^{81}$ Thus, when the Democrats offered better reform alternatives after George W. Bush came into office, they proved unable to dent the pro-repeal coalition — even though small businesses

74. Id.

75. Thigpen is the African-American farmer mentioned immediately above. See also id. at 41 (mentioning the case of Representative Jennifer Dunn, a single mother who raised two boys alone).

76. E.g., id. at 255. Repeal zealots failed to mention that we do this all the time. For example, the same person can have to pay income, consumption, capital gains, and gift tax - all on the same money.

77. Runciman, Rich Murderers, supra note 45, quoting anti-tax advocate Grover Norquist. See also id. at 140-41, 213-14 (same), 236 (noting that some Americans actually found this argument credible).

78. DeAth By a Thousand Cuts, supra note 5, at 85-98.

79. Id. at $19-20,120-30,254-55$.

80. Id. at $99-106,259-65$.

81. Id. at $34-40,45-47,134,216,259-60$. 
and farmers could have benefited more from reform than from the repeal bill that passed. Everyone was too afraid of another QFOBI. ${ }^{82}$

For their part, charities and other non-profit organizations could not come out against repeal, since many of their board members were wealthy and stood to lose if repeal failed. ${ }^{83}$ The insurance industry proved similarly hamstrung. That industry benefits when business owners and farmers buy insurance to pay the estate tax, but it, too, suffered from internal conflicts. A Republicandominated industry, it hesitated to cast its lot with an opposition composed largely of Democrats and populist reformers like Ralph Nader. Moreover, it feared that any opposition to the repeal movement might strike the public as simple nest-feathering. ${ }^{84}$

Organized labor sat the campaign out for a different reason. Although tax repeal stood to hurt a huge majority of unionists, their movement was beset with more serious problems, including the collapse of collective bargaining, trade policy, and holding the line against union-busting tactics and downsizing, and so could mount little serious resistance (pp. 107-12).

With the odds increasingly on the side of repeal, it was easy to gain access to Congress and President Bush. Graetz and Shapiro thus devote most of an entire section ("The Battle for Passage," pp. 131-218; see also pp. 41-49) to legislative events leading up to repeal in 2001. The reader with any illusions about the rectitude or transparency of the legislative process will come away chastened. This portion of the book is a disturbing look at power politics in Washington. With profiles of the movers and shakers, the reader comes to see clearly how not all Congress people are equal on the Hill and how much current-day politics resembles a used car lot.

In the end, the pro-repeal movement did not get everything it wanted. Congress repealed the tax only for people who die between January 1 and December 31, 2010. The reform phases out the top rate gradually, so that it bottoms out in 2009, leaving the estates of most of those who die in the next year - 2010 - free from paying any tax at all. At the same time, the exemption rises year-by-year beginning in 2001 and will top out at \$3.5 million in 2010 . The gift tax (which targets wealthy people who try to give away their estates in anticipation of their death) remains in place with a $\$ 1$ million lifetime exemption. ${ }^{85}$

\footnotetext{
82. Id. at 36 .

83. Id. at $116,129,168,246-47$.

84. Id. at $115-16,133-34,247$.

85. Id. at 201-02.
} 
Not entirely satisfied, the movement continues clamoring for permanent repeal and appears likely to continue to do so in the years remaining before the 2001 provisions sunset. Moreover, they appear to have their eye on other provisions of the tax code, as well as on broad-based measures such as the "fair tax" (national sales tax in lieu of corporate, income, payroll, and estate tax) and the "flat tax" (a single-rate tax on consumption) ${ }^{86}$

Graetz and Shapiro conclude with a warning that further efforts are likely to strike at the very heart of our tax structure: its progressive nature. ${ }^{87}$ Unless ordinary citizens learn how these reforms will damage their interests and begin to see through the web of narratives that supported the first conservative breakthrough - repeal of the estate tax - the tax system, designed to offset some of the wealth inequality in our country, will turn into a weapon to dramatically increase the wealth gap. ${ }^{88}$ Upward mobility will suffer serious erosion - the victim, ironically, of its own narrative — and the tax system will be dismantled by a thousand cuts.

\section{B. Charles Murray, A Plan to Replace the Welfare State}

Charles Murray's trademark is intellectual audacity. His The Bell Curve $(1994)^{89}$ argues that genetics, not the environment, determines most of a person's mental ability (IQ) and that some races have more of it, on average, than others. Moreover, the current distribution of roles in American society is a product of differing human talents, thus we should not be surprised if most basketball stars, rocket scientists, and agricultural workers are of different hues.

Losing Ground $(1984)^{90}$ is a sustained attack on the welfare state that seeks to demonstrate that our system of support worsens the poor's predicament. By sapping initiative and encouraging dependency, programs like AFDC (Aid to Families with Dependent Children) weaken family bonds and encourage men to desert the home and women to have more babies than they can afford. Over the years, he has addressed other controversial topics,

86. Id. at $28,270-71,273-77$.

87. Id. at $4,10,266-82$.

88. Id. at $266-82$.

89. Richard J. Herrnstein \& Charles A. Murray, The Bell Curve: Intelligence and Class Structure in American Life (1994) [hereinafter Herrnstein \& Murray, Bell Curve].

90. Charles A. Murray, Losing Ground: American Social Policy, 1950-1980 (1984). 
such as political correctness on college campuses, crime, and whether women have less ability at math and science than men. ${ }^{91}$

In his new book, A Plan to Replace the Welfare State, ${ }^{92}$ Murray revisits the subject matter of his first. Like Losing Ground, the new book grapples with poverty, race, and the role of government in addressing inequality. No progressive reformer, Murray holds that the solution to these problems does not lie in new programs, better schools, or new forms of welfare. Instead, like other supply-side compatriots, he wishes to harness the power of the marketplace. ${ }^{93}$ By allowing the productive sector to operate with as few restrictions as possible and giving individuals an incentive to work and better themselves, his flat-grant scheme will revitalize the nation. Capital and entrepreneurs with ideas will find each other. A rising tide will lift all boats, and all sectors of the economy will flourish.

Murray begins by pointing out that America's population today is richer than ever before, and that the United States is, at least by certain measures, the wealthiest nation in the world. ${ }^{94}$ Annually, the state and federal government distributes more than one trillion dollars of that wealth to alleviate sickness, unemployment, poverty, and other social ills. ${ }^{95}$ Yet, many Americans still lack health insurance, while stubborn unemployment and under-employment haunt our cities. ${ }^{96}$ Even the middle class are insecure about their retirement and worry about the viability of the Social Security System. ${ }^{97}$

Since the government has been spending its money so ineffectually, Murray proposes that it stop trying and instead give the money to the people to use as they wish. ${ }^{98}$ This is what he calls "the Plan," a breathtakingly simple proposal that Murray says defies any political label. ${ }^{99}$ (He is quite wrong about that: It is libertarian.) His Plan would eliminate all welfare transfer programs - federal, state, and local-including Social Security, Medicare, Medicaid, HeadStart, and the Earned Income Tax Credit in favor of an annual

91. See Mr. Murray's entry on The American Enterprise Institute's website (AEI Online), http:// www.aei.org/publications/filter.all,pubID.23481/pub_detail.asp (last visited May 29, 2006). See also remarks of Chris DeMuth, in id. (Book Forum); Charles Murray, Sex Ed at Harvard, N.Y. Times, Jan. 23, 2005, at A17 (Op. Ed.).

92. See Murray, supra note 8.

93. Id. at 2-4, 59-60, 62-64, 66-70.

94. Id. at 1 .

95. Id.

96. Id. at 1, 24-71.

97. Id. at 1, 24-36.

98. Id. at 1, 2, 8-14.

99. Id. at 8-14; see also Charles Murray, The $\$ 10,000$ Solution, in AEI Online, supra note 91 (describing his plan as aimed at what the left and the right would consider common ground). 
$\$ 10,000$ cash grant to everyone age 21 or older and not in prison. ${ }^{100}$ It would also mean that Congress could not give subsidies to favorite industries, such as agriculture. ${ }^{101} \mathrm{He}$ discusses the advantages of such a plan and how to put it into effect.

Separate sections show how the plan would affect current areas of welfare spending, including health, ${ }^{102}$ retirement, ${ }^{103}$ relief of poverty, ${ }^{104}$ and the family. ${ }^{105}$ Other sections address how reducing the role of government would strengthen social bonds and encourage a spirit of entrepreneurship. ${ }^{106}$ (Inventors, musicians, and artists could use the \$10,000-a-year grant as seed money to set up a new company, band, or art gallery.) Upward mobility, now doubly hampered by heavy taxation and welfare-induced dependency, would soar.

After demonstrating his Plan's feasibility, Murray goes on to show how most of the functions of the welfare state - caring for children, protecting the weak and homeless, assuring a safe retirement for those past their earning years - would flourish if left to individuals, rather than to the state. ${ }^{107} \mathrm{He}$ also shows how his approach would strengthen initiative and self-reliance, as individuals who now look to the government to supply vital services realize that they can do so better for themselves. ${ }^{108}$

Just as the Plan would eliminate the need for a large federal bureaucracy, it would harness the power of the market to drive down the cost of services. An individual needing medical care, for example, would seek out the doctor or hospital capable of treating his or her ailment best and at the most reasonable price. ${ }^{109}$ The resulting competition among caregivers and pharmaceutical companies would help contain soaring health care costs. With Medicare, for example, patients have no incentive to cut down on hospital visits or to choose the most efficient form of care; under Murray's plan, they would. ${ }^{110}$

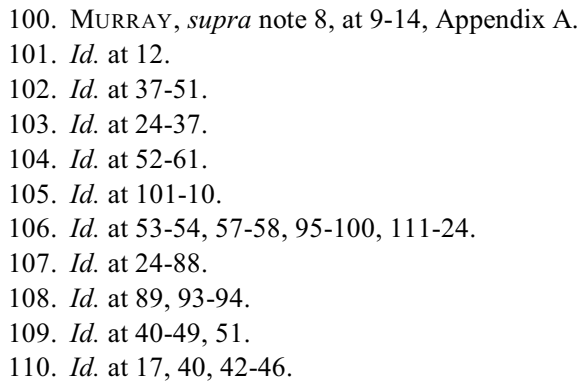


The last section of his book, entitled "The Larger Purpose," urges that Murray's scheme not only will save the average American money, it can revitalize America culturally and spiritually. ${ }^{111}$ Citizens will approach life with alacrity. Realizing that their fate lies in their own hands, their decisions will take on new meaning. Excitement and individual enterprise will replace drone-like drudgery and apathetic reliance on outside forces and the government. ${ }^{112}$ Self-respect will flourish. By reclaiming their lives from the bureaucracies that currently control them, ordinary citizens will discover resources within themselves. They will learn to turn to their families, churches, and neighborhoods for help. These institutions will grow and strengthen, and America will become more vibrant. ${ }^{113}$

Murray even evokes Aristotle (while barely mentioning him) in praise of his Plan. By turning to their own resources, citizens will develop compassion, honesty, and self-reliance. Aristotle wrote that only through practicing virtue and making it habitual will one develop a good character. By learning to do for ourselves, our children, our families, and our neighbors what the government currently does for us, America will become a nation of trustworthy, caring, and socially responsible individuals who not only preach generosity, prudence, thrift, and foresight, but practice them in their daily lives. ${ }^{114}$ Seeing others act in this fashion would encourage us to behave similarly, since we would realize it was expected. And as America gradually turned into a caring community of law-abiding people, we could let down our guard somewhat. Some of the energy we now spend building gated communities and installing burglar alarms would find more productive uses. ${ }^{115}$

Is Murray serious? And, is his Plan remotely feasible? It is a big mistake to underestimate Charles Murray. When he wrote Losing Ground in 1984, critics scoffed. Yet, it became law in only twelve years with the Welfare Reform Act of 1996. ${ }^{116}$ Just a few years ago, The Bell Curve with its neoeugenicist tenor struck many readers as repugnant and radical; today, it is well on its way toward becoming the reigning orthodoxy. ${ }^{117}$

111. Id. at $81-124$.

112. Id. at $83-85,89-94$.

113. Id. at $95-124$.

114. Id. at $92-94,117-24$.

115. Id. at 116-17.

116. 42 U.S.C.A. $\S 601$ (2005).

117. DeMuth, supra note 91 (describing Murray's view as "well on its way to becoming conventional wisdom"). 
Murray clearly does not regard his current book as a mere thought experiment or debating point, ${ }^{118}$ and his readers should not either. Even if Congress is unlikely to enact it anytime soon, the lesson Graetz and Shapiro's book teaches is that conservative ideas often have great staying power. ${ }^{119}$ Murray's scheme has solid roots; Milton Friedman proposed something similar not too long ago, and before him George Stigler, ${ }^{120}$ and think-tank conservatives have been talking about it for years. A proposal like Murray's could easily surface in Congress or some bellwether state like California in the not too distant future.

If so, Murray will have laid much of the groundwork. Consider how several sections of his book address the Plan's practicability and how to put it into effect. ${ }^{121}$ Others, which discuss likely objections to his scheme, are practically a how-to guide for future legislators. For example, the grant is not really flat. Although the vast majority of Americans will qualify for the full $\$ 10,000$, above an annual income of $\$ 25,000$ the grant starts to be taxed, and at $\$ 50,000$ recipients stop paying taxes on the grant but the government takes back the first $\$ 5,000 .{ }^{122}$ This compromise with our current scheme of progressive income tax avoids the objection that the grant goes to rich people who would just use it for summer homes, a third car, or a European vacation.

Murray also deals with the possibility that the grant might be a disincentive to work, particularly for young adults. Murray takes this objection seriously, devoting an entire chapter to it. ${ }^{123}$ His main response is that people who are currently idle will not become less likely to work by reason of having $\$ 10,000$ a year, but more. ${ }^{124} \mathrm{He}$ also deals with disincentives for high earners making $\$ 40,000$ a year or more by doubting that they would react to taxation of their grant by stopping work altogether. Most individuals in that bracket find their work so rewarding that they are unlikely to stop merely because their income level subjects a small part of that income- the $\$ 10,000$ of the flat grant - to a tax. ${ }^{125}$

118. See Murray, supra note 8, at 125-27.

119. See supra Part IIA (discussing Death By a Thousand Cuts).

120. E.g., DeMuth, supra note 91. See also id. at xii, 8 (mentioning role of Friedman and Stigler in championing a negative income tax).

121. Murray, supra note 8, at 15-22, Appendices A-E.

122. Id. at 11 .

123. Id. at $72-81$.

124. Id. at 73-78.

125. DeMuth, supra note 91 (placing this interpretation on Murray's discussion of work incentives). See also Charles Murray, A Plan to Replace the Welfare State, WALL St. J., Mar. 22, 2006 (also in AEI Online, supra note 91) (mentioning that for readers of the Wall Street Journal their work gives life much 
Murray also devotes attention to the plan's cost. Giving $\$ 10,000$ to every American, even coupled with ending most transfer payments, would be more costly than the current scheme. ${ }^{126}$ But with the escalating costs of such programs as Social Security and Medicare, that balance will shift in the near future. By the year 2011, Murray's plan will cost as much as it saves. After that, it will start to be much cheaper. By the year 2020, the Plan would cost about half a trillion dollars less per year than the current system, by 2028 a trillion dollars less. ${ }^{127}$

What about Congress's weakness for the pork barrel? Might not legislators attach a series of strings to the grant, or exempt favorite transfer programs (such as the subsidy for corn farmers) from abolition? Murray deals with that risk by means of a constitutional amendment that, apart from his cash grant, prohibits the government from engaging in any form of redistribution - that is, from taking from A to give to B. ${ }^{128}$ The purpose of the amendment is effectively to outlaw social programs at every level of government-federal, state, and local. Schools, the military, police, highways, and the legal system would be exempted. ${ }^{129}$

In the words of one commentator, the book does for the social benefits side of government what the flat tax does for the revenue side. It takes the universe of government subsidy programs and transfer payments, cashes them out, and hands them back again on the basis of per-citizen equality. ${ }^{130}$ It then forbids the government from doing anything further. Aside from the grant, redistribution will come to a complete and permanent halt.

\section{Evaluation}

Both books are well written, fast paced, and very good reads. Graetz and Shapiro tell an engrossing story, building toward a climax, with the rich detail, attention to characterization, and suspense of a good detective tale. Murray's book is short, a bare 127 pages long, equally well written and featuring what must be one of the highest ideas-to-page ratios of any recent book. Both address vital social problems - progressive taxation, poverty, social mobility,

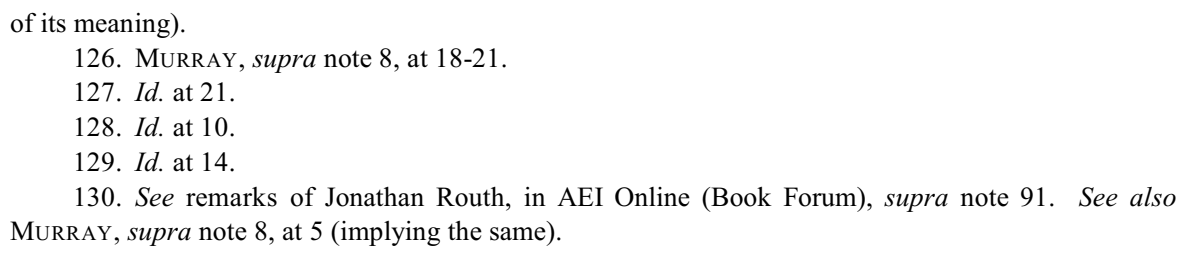


the rising cost of entitlements, and the proper line between governmental and individual responsibility — with imagination and flair.

Graetz and Shapiro's book is the more descriptive of the two, Murray's the more prescriptive. He has a program for America and wants his readers to sign on to it. It is tempting to find fault with the Murray book because of its somewhat sweeping character. For example, one wonders what provision Murray would make for those who are too dim or short-sighted to put their yearly grant to good use or run through it in the first month or two by partying with their friends and buying luxury items. Murray believes that many of his fellow citizens are not very smart, ${ }^{131}$ yet his new book seems to make little allowance for that weakness.

One is also tempted to ask why eliminating social programs would bring human happiness, as Murray writes, when the most contented people seem to live in European countries with high taxation, long vacations, and guaranteed health care. ${ }^{132}$ And what about this country's very large jail population? Perhaps as a concession to his conservative constituents, Murray would exempt prisoners from the $\$ 10,000$-a-year grant, ${ }^{133}$ but what, exactly, is an exfelon to do when he gets out of prison only to find all the halfway houses, free clinics, and government-operated job centers closed?

Still, the books constitute impressive efforts to address serious social problems and should be on the shelf of every reader interested in this country's future. Running through both of them, one issue looms large: upward mobility. Graetz and Shapiro want to provide for it by taxing the rich for the benefit of the poor. Their spirited defense of the estate tax is, in part, an effort to reclaim upward mobility, and make the rich-who already have enjoyed the fruits of it - pay for more of it for the rest of us. They also worry about the many citizens who voted for repeal because of an exaggerated view of their chances for later-acquired wealth. Believing that they would one day

131. See Herrnstein \& Murray, Bell Curve, supra note 89. Murray also seems to overlook the issue of inflation. Putting that much money into the hands of every citizen could lead to rapid inflation which, in turn, could decrease the future buying power of the $\$ 10,000$ grant.

132. Murray believes that human happiness comes from taking responsibility for one's fate, being in control of one's finances and time, and not relying on others for vital services or needs. But if he means this as an empirical assertion, it is open to doubt. European citizens report high levels of satisfaction with their lives even though they pay high taxes, visit state-sponsored medical clinics, take long vacations, and live in houses much like those of their neighbors. Cf. Janny Scott \& David Leonhardt, Class in America: Shadowy Lines That Still Divide, N.Y. Times, May 15, 2005, at A1 [hereinafter Scott \& Leonhardt, Shadowy Lines].

133. MurRay, supra note 8 , at 16 . 
be effortlessly rich, they voted against a tax that would help them and their class move slowly but surely ahead.

Murray embraces the opposite view. For him, we already do too much taking from the rich for the benefit of the poor. Government spends our money unwisely, discouraging individual initiative and free enterprise in the process. Getting government out of the redistribution business would return responsibility to the right hands - the ones that earned the money in the first place - and let each of us be the master of our own fate.

The differences between the two sets of authors, then, are partly ideological and partly factual. The ideological differences are largely a matter of personal predilection. This reviewer prefers Graetz-Shapiro's approach, but others might easily prefer Murray's. We can, however, investigate two factual respects in which the two books differ. One concerns the actual amount of upward mobility in U.S. society, the second the current ideology and mindset of empowered actors.

On the first issue, social science favors Graetz and Shapiro: The world of upward mobility is more like what they describe than what Murray posits. ${ }^{134}$ Few people change social class, and when they do the going is hard and their new foothold insecure. But courts and many legislators ignore these truths and side with Murray. ${ }^{135}$ Ideologically, the current legal system is aligned with his libertarian view that upward mobility is wide open and the role of government is to stay out of the way and let individuals rise or fall on their merits. Indeed, our system of law and politics is increasingly premised on the myth of upward mobility, with troubling consequences. As the gap between the haves and the have-nots increases, might we one day need judges and legislators uncommitted to unrealistic myths and ready to accept the challenge of crafting institutions and case law that will enable talent, wherever found, to emerge?

\section{Upward Mobility in American Society}

American society, especially today, exhibits much less upward mobility than most people think and certainly less than popular sources would suggest. The extent to which poor individuals are able to work their way up the ladder falls somewhere between the worlds of Graetz-Shapiro and Murray, but much closer to the former. Recent studies show that the United States has one of the

134. See Part III, infra ("Upward Mobility in American Society").

135. See infra Part IV ("Official Construction of Upward Mobility"). 
lowest rates of upward mobility in the developed world and that few citizens leave the class into which they are born for a higher one. ${ }^{136}$ Downward mobility is just as common as the upward variety, particularly for African Americans, but also for the middle class in general. ${ }^{137}$ Eighty percent of an average citizen's wealth is inherited, not created. ${ }^{138}$

One of the more arresting figures that emerges from studies of upward mobility is that a person born in the lowest economic stratum has only about a two percent chance of ending life anywhere near the top. ${ }^{139}$ Poorly staffed and funded schools in poor and working-class neighborhoods, inadequate prenatal nutrition and health care, environmental hazards and toxins, cutbacks in affirmative action, downsizing, and relocation of industrial jobs away from the inner cities are just some of the factors that weigh against a poor youth seeking to better himself. ${ }^{140}$ The military, for most, is a dead-end job (and not even open to those with a criminal record or poor health history), while our country's current obsession with incarceration and prison-building renders even more young men and women unemployable every day. Outsourcing, the weakening of unions, and the loss of skilled jobs are additional hurdles. Most new jobs are in the "soft" low-wage, low-skill service sector. ${ }^{141}$

The Federal Reserve Bank of Boston found that fewer families moved from one quintile of the income ladder to a higher one during the 1980's than during the 1970's, and that fewer still moved up in the 1990's than the 1980 's. ${ }^{142}$ A second, even larger study by the Bureau of Labor Statistics also found that mobility declined during the latter period. ${ }^{143}$ Even though the

136. See Scott \& Leonhardt, Shadowy Lines, supra note 132, at A1 (noting that researchers believe upward mobility in the United States may be declining).

137. On downward mobility for African Americans, see Debra B. McBrier \& George Wilson, Going Down? Race and Downward Mobility for White-Collar Workers in the 1990s, 3 Work \& OcCupation 283 (2004). On the painfully slow upward climb of Latino immigrants, often requiring four generations or more, see Anthony DePalma, 15 Years on the Bottom Rung: Mexican Immigrants and the Specter of an Enduring Under Class, N.Y. Times, May 26, 2005, at A1. On the stagnating fortunes of the middle class, see text and notes 1-2, 16, 18-19 supra, 139, 157, 167-70 infra.

138. See Laurence J. Kotliff \& Lawrence H. Summers, The Role of Intergenerational Transfer in Aggregate Wealth Accumulation, 84 J. Pol. Econ. 4 (1981); Daria Roithmayr, Them That Has, Gets (unpublished, on file with author); Dalton Conley, Being Black 47 (1999).

139. Various reports place this figure as between one and two percent. E.g., Gary Solon, Intergenerational Income Mobility in the United States, 82 Am. Econ. Rev. 3 (1992); Who's Classier?, Chron. Higher Ed., June 1, 2005 (Careers) (reporting figure of one to two percent).

140. E.g., Edelman, Race Meets Class, supra note 17, at 5.

141. See Frederick R. Strobel \& Wallace C. Peterson, The Coming Class War and How to Avoid It: Rebuilding the American Middle Class 111-12 (1999).

142. Scott \& Leonhardt, Shadowy Lines, supra note 132, at A17.

143. Id. 
economic upturn of the late 1990's lifted pay rates for low-income jobs such as janitor and clerk, most occupants of those positions remained there- they were still janitors and clerks at the end of the boom years. ${ }^{144}$ Between 1973 and 2000, the real income of the bottom 90 percent of American workers actually fell by 7 percent. ${ }^{145}$ (That of the top 1 percent rose by 148 percent, while that of the top 0.1 percent rose by 343 percent and of the top 0.01 percent by 599 percent. ${ }^{146}$ ) Although family income rose slightly during some of that period, much of the rise was due to the entry of wives into the paid labor force and men working longer hours or at second jobs. ${ }^{147}$ Inequality in the United States has risen to levels not seen since the Gilded Age of railroad and steel robber barons, and exceeds that of Europe or Canada. ${ }^{148}$ The Federal Reserve found that in a recent year, the richest one percent of U.S. households controlled half of all of the nation's financial assets. ${ }^{149}$

One recent study found that because of those sharp disparities, an American child's economic background is a better predictor of his or her school performance than in Denmark, the Netherlands, or France. ${ }^{150}$ According to one scholar, "being born in the U.S. gives you a constellation of privileges that very few . . . in the world have ever experienced. Being born poor in the U.S. gives you disadvantages unlike anything in Western Europe and Japan and Canada." 151 In the U.S., holding a college degree is a major determinant of who gets to enter middle class life. But college is attainable mostly by those whose families already have wealth or education. Although college enrollment has risen for higher-income students, most children from

144. James Lardner, Upward Mobility Should Get Easier, Not Harder: More People are Stuck Running in Place, at http:www.progress.org/2004/labor06.htm (last visited July 27, 2005) [hereinafter Lardner, Easier Not Harder].

145. Paul Krugman, The Death of Horatio Alger, Our Political Leaders are Doing Everything They Can to Fortify Class Inequality, THE NATION, Jan. 5, 2004 [hereinafter Krugman, Death of Horatio Alger].

146. Id. See also David Cay Johnston, Richest are Leaving Even the Rich Far Behind, N.Y. TimES, June 5, 2005, at A1, A17 [hereinafter Johnston, Richest are Leaving], noting that "economic mobility — moving from one income group to another over a lifetime — has actually stopped rising in the United States .... Some recent studies suggest it has even declined over the last generation"; Geraldine Fabrikant, Old Nantucket Warily Meets the New, N.Y. Times, June 5, 2005, at A1 (describing mores of the new "hyper-rich" class).

147. Krugman, Losing our Country, supra note 16.

148. Krugman, Death of Horatio Alger, supra note 145.

149. See Woody Holland, Money at the Top: Let's Tax Inheritances of the Rich Since Corporate Capitalism Leaves Out "Less-Skilled" Workers, Pittsburgh Post-Gazette, Nov. 8, 2005, at E8 [hereinafter Holland, Capitalism Leaves Out].

150. Scott \& Lenhardt, Shadowy Lines, supra note 132, at A17.

151. Id., quoting Professor David I. Levine, UC-Berkeley economist and mobility researcher. 
poor homes can only afford to go to community colleges, which in most cases do not offer bachelor's degrees. ${ }^{152}$

The number of students from very poor families who earn a college degree was less than 5\% in a recent year, a figure that has barely budged over the last three decades. ${ }^{153}$ The number from the bottom quarter who earned a degree was only 8.6 percent; from the top quarter, 74.9 percent. ${ }^{154}$ Russ Douthat writing in the Atlantic Monthly notes that a child growing up in a family earning over $\$ 90,000$ a year has a 50 percent chance of earning a college degree by age $24 .{ }^{155}$ A child in a family earning $\$ 35,000$ to $\$ 60,000$ has a 10 percent chance; and one in a family earning under $\$ 35,000$ a 6 percent chance. ${ }^{156}$ Part of the reason for low college completion is dropout: The relatively few students from low-income families who do enroll in a fouryear college often disenroll, for reasons ranging from poor preparation to not having enough money to continue. ${ }^{157}$ This poor record is not from lack of interest. According to the N.Y. Times, 43 percent of those who did not graduate from college considered a college degree essential to success; 32 percent of high school dropouts did, as well. ${ }^{158}$

At 250 of the most selective colleges, the proportion of students from upper-income families has grown, not shrunk, in recent years. The median family income of a Harvard student is $\$ 150,000 .{ }^{159}$ According to Princeton's Educational Testing Service, only three percent of the freshmen at the top 146 colleges and universities come from the poorest quarter of American families. ${ }^{160}$ Competitive schools are beginning to use merit-based financial aid to attract talented students who might be tempted to enroll at one of their competitor schools, rather than need-based financial aid that helps poor students receive a college education. ${ }^{161}$ Even the federal government, which has served as a traditional source of financial aid, is shifting resources from

152. Lardner, Easier Not Harder, supra note 144. See also David Brooks, The Education Gap, N.Y. Times, Sept. 25, 2005, at 11 (same) [hereinafter Brooks, The Education Gap].

153. Lardner, Easier Not Harder, supra note 144.

154. Brooks, The Education Gap, supra note 152.

155. David Brooks, Pillars of Cultural Capital, N.Y. Times, Oct. 6, 2005, at A35.

156. Id.

157. See David Leonhardt, The College Dropout Boom: Working Class and Staying That Way, N.Y. Times, May 24, 2005, at A1, A18 [hereinafter Leonhardt, Dropout Boom].

158. Id.

159. David Brooks, Karl's New Manifesto, N.Y. Times, May 29, 2005, at 11.

160. $I d$.

161. Leonhardt, Dropout Boom, supra note 157. 
Pell grants, most of which go to families with incomes below $\$ 41,000$, to other forms of aid. ${ }^{162}$

In addition to inadequate educational opportunities, poor people are less likely than their more fortunate counterparts to enjoy good health because of environmental conditions such as pollution, toxic waste, lead paint, and substandard nutrition. ${ }^{163}$ They are also less apt to have access to basic health insurance and care, in part because the United States is the only developed nation without some form of universal health insurance. ${ }^{164}$ Upper-middleclass Americans live longer and are in better health than middle-class Americans, who in turn live longer and are healthier than those at the bottom. ${ }^{165}$ Moreover, these class differences are widening, not closing. ${ }^{166}$ The infant death rate for African Americans in Washington, D.C., is higher than it is in Kerala, India. ${ }^{167}$ Even overall, the U.S.'s statistics are poor. The 2005 Human Development Report pointed out that the infant mortality rate in the U.S. was roughly equal to that of Malaysia. ${ }^{168}$

Data from the Internal Revenue Service show that those who file estate tax returns have lived, on average, three years longer than the general population. ${ }^{169}$ In addition to living longer, the wealthy enjoy better health and vitality during their lives. Americans who report that they are in excellent health have 74 percent more wealth than those who report fair or poor health. The reason is simple: Both prevention and intervention are more widely available to the affluent. ${ }^{170}$ Poor health, of course, leads to low earnings, and

162. Ever Higher in Society, Ever Hard to Ascend: Meritocracy in America, Economist, Jan. 1, 2005 (online at http://www.lexisnexiscom/lawschool). We often tell ourselves that our society is merit based. What we ignore is how "merit ... is at least partly class-based. Parents with money, education and connections cultivate in their children the habits that the meritocracy demands. When their children then succeed, their success is seen as earned." Scott \& Leonhardt, Shadowy Lines, supra note 132.

163. On the environmental justice movement, see, e.g., Luke W. Cole \& Sheila R. Foster, From the Ground Up: Environmental Racism and the Rise of the Environmental Justice Movement (1999); David N. Pellow \& Lisa S. Park, The Silicon Valley of Dreams: Environmental Injustice, Immigrant Workers, and the High-Tech Global Economy (2002).

164. See, e.g., Janny Scott, Life at the Top in America Isn't Just Better, It's Longer, N.Y. Times, May 16, 2005, at A1 [hereinafter Scott, Life at the Top]. See also Jill Quadagno, One Nation, Uninsured: Why the U.S. Has No National Health Insurance (2005).

165. Scott, Life at the Top, supra note 164. The death rate for black children in Washington, D.C., is higher than that of Kerala, India, $i d$.

166. Id. Hurricane Katrina showed that one's social class is also a good predictor of how quickly the government will come to one's aid in the event of a natural disaster. See, e.g., Gabrielle Forks, Katrina Has Left Gulf Coast Poor at a "Fork in Road," Pittsburgh Post-Gazette, Sept. 18, 2005.

167. Holland, Capitalism Leaves Out, supra note 149.

168. Id.

169. Scott, Life at the Top, supra note 164.

170. Id. 
so on in a cycle. Most people who have health insurance have it through their jobs. Those without jobs or who do temp work (the fastest-growing sector of the economy) usually lack health insurance altogether.

As seen earlier, abolition of the estate tax will increase the tax burden on the poor and middle class. ${ }^{171}$ But that is not the only respect in which the tax system operates as a barrier to those groups. Originally aimed at reducing income disparities among citizens, the progressive income tax is starting to vanish. Most deductions today benefit those with wealth. For example, a taxpayer can deduct mortgage interest on two homes, which rewards those with sufficient income to buy a second dwelling. The deduction now covers the mortgage interest on all types of homes - even a boat that serves as a second home. Home equity loans are just as deductible as mortgages, and the proceeds of the loan need not go to home-buying; they may be used to purchase a car or vacation while writing off the interest. ${ }^{172}$

In the 2004 presidential election, the Republican candidate insisted that most of the latest tax cuts would go to the middle class. In reality, 53 percent will go to people with incomes in the top 10 percent. ${ }^{173}$ More than 15 percent will go to just the top 0.1 percent, a small circle of about 145,000 taxpayers. ${ }^{174}$ The alternative minimum tax, created 37 years ago to assure that the very richest paid taxes, has never been adjusted to take account of inflation, so that families making between $\$ 75,000$ and $\$ 200,000$ annually pay thousands of dollars in taxes that originally targeted only a few of the very wealthiest. If President Bush's cuts become permanent, in a decade those making between $\$ 100,000$ and $\$ 200,000$ will pay about 5 to 9 percent more in federal taxes than those making over $\$ 1$ million, and the gap will yawn even wider for those further down the line. ${ }^{175}$ Meanwhile, bankruptcy "reforms" have made it even harder for poor people to dig themselves out of debt and start anew. ${ }^{176}$

Unsurprisingly, their number is rising. Poverty in the United States rose from 11.7 percent in 2001 to 23.1 percent in 2002. ${ }^{177}$ And, although the United States is one of the world's richest countries, the United Nations Development Programme reports that on its Human Poverty Index, which

171. See supra Part IIA.

172. Strobel \& Peterson, supra note 141, at 146-48 (explaining how the rules of the mortgage interest deduction favor the wealthy).

173. See Johnston, Richest are Leaving, supra note 146, at 17.

174. Id., pointing out that "The Bush administration tax cuts stand to widen the gap between the hyper-rich and the rest of America."

175. The Bush Economy: New Hope for the Fabulously Wealthy, N.Y. TimEs, June 7, 2005, at A22.

176. Krugman, Losing our Country, supra note 16.

177. U.S. Bureau of the Census (2003d, 2, tbl. 1). 
combines illiteracy, poverty, unemployment and life expectancy, Sweden ranked first among developed nations and the United States last. ${ }^{178}$ The U.S. also had the largest percentage of children (20.3 percent) living in poverty. ${ }^{179}$ Those children are not only poor for a longer period of time than in countries like Germany, they are more likely to remain so when they grow up. ${ }^{180}$ In the face of figures like these, an objective observer assessing the chances of a typical poor child to enjoy any kind of serious upward mobility in life would assess them as very low.

Upward mobility, especially for children of working-class parents, is so unusual that those who do rise to positions such as university professor feel like freaks. ${ }^{181}$ They find themselves the only ones who do not know which fork to use at a faculty dinner party, how to sail, or what rich people do in Monaco or Aix-en-Provence. A recent spate of books and articles discuss how isolated and insecure such people feel. ${ }^{182}$ As the only one in their circle with working-class origins, they find few colleagues who understand their background or the difficulty they feel in fitting in to their new settings. ${ }^{183}$

Despite this evidence, most Americans are optimistic about their chances of getting ahead. Forty percent believed that movement from one class to another had improved over the last 30 years; in fact it has declined. ${ }^{184}$ Even families earning less than $\$ 30,000$ cling to the American dream, more than half saying that they are either living it now or expect to do so soon. ${ }^{185}$ Many of these are the same people who say they oppose the government's taxing of

178. United Nations Human Development Programme, Human Poverty Index 249 (2003).

179. Lee Rainwater \& Timothy M. Smeeding, Poor Kids in a Rich Country: American Children in Comparative Perspectives 21 (2003). Rainwater and Smeeding also found that U.S. children are likely to be poor longer than in other countries they studied and less apt to move out of poverty, Rainwater \& Smeeding, id.

180. Id. at 67.

181. See Tamar Lewin, Up from the Holler: Living in Two Worlds, At Home in Neither, N.Y. Times, May 19, 2005, at A1 [hereinafter Lewin, Up from the Holler]; This Fine Place So Far From Home (C.L. Barney Dews \& Carolyn Leste Law eds., 1995) [hereinafter Fine PlaCe]; Carolyn Alessio, When College Advising Must Cross Cultural Gaps, Chron. Higher Ed., July 7, 2006 (Admissions \& Student Aid).

182. E.g., Fine Place, supra note 181; Lewin, Up from the Holler, supra note 181, at A18 (describing a child from a poor family in Appalachia who left for college and law school: "But Ms. Justice still felt like an outsider. Her co-editors on the law review . . . all seemed to have a wealth of information that had passed her by.").

183. See sources cited supra note 177. See also Matthew H. Gendle, Moving on Up, CHron. HighER ED. (CAREERS), Apr. 13, 2006.

184. See Scott \& David Leonhardt, Shadowy Lines, supra note 132. See also Death By A THousand CuTs, supra note 5, at 119-20; text at supra note 16 .

185. See Scott \& Leonhardt, Shadowy Lines, supra note 132, at 16. 
a person's estate at the time of his death. ${ }^{186}$ Individuals who describe themselves as conservatives tend to say that mobility is wide open. (Liberals and progressives like Graetz and Shapiro are much more guarded.) In a 1987 speech, Gary Becker, the University of Chicago economist who later won a Nobel Prize for his studies of the welfare system, said that mobility in the United States stood at such a high level that advantages passed on from parents accounted for very little of a child's life chances. ${ }^{187}$ Subsequent investigation has refuted that judgment; most social scientists now say that the early studies on which he based his statement were flawed, relying on children's fuzzy recollections of their parents' incomes or misconstruing the normal progress a person makes in his profession (for example, from young associate in a law firm to partner) as upward mobility. ${ }^{188}$

If even a prominent economist can be wrong about the extent of upward mobility, what about judges? Courts are supposed to rely on evidence, not hunches, country club gossip, or intuition. What has been their role vis-à-vis the myth of upward mobility? Have they sifted and weighed the evidence, as the reporters who compiled a massive New York Times study of upward mobility, or a similar study reported in the Wall Street Journal, or a myriad of recent social science articles and books (or, indeed, this review) have done? Or have judges simply enshrined in their opinions the attitudes and beliefs of members of their class?

\section{The Official Construction of Upward Mobility}

In everyday parlance, a myth is a statement that is untrue yet believed by a substantial segment of the population. Study after study shows that class membership in our society is relatively fixed, especially for those born into poor families, who are racial minorities, or who lack a college education. ${ }^{189}$ Nevertheless a large portion of the population believes that the sky is the limit. Conservatives, the wealthy, and tax reformers have a special investment in this pleasant fable, which provides a justification for their good fortune at the same time that it enables them to cast the blame on the rest of us for not prospering as they have done. ${ }^{190}$

186. See supra Part IIA.

187. Scott \& Leonhardt, Shadowy Lines, supra note 132, at A17.

188. Id.

189. See supra Part III.

190. See text and notes 3-5, supra. 
What about courts, legislators, and other empowered actors? Do they, too, contribute to the myth of upward mobility? As will be seen, they do so with a regularity and a certitude even surpassing those found in the working class or popular fiction. But with governmental actors, a further irony appears - at the same time that they celebrate the virtues of upward mobility, they have been slamming the door shut on the real thing.

\section{A. Presidents, Legislators, and Other Public Figures}

Presidents, legislators, and other public figures have praised upward mobility lavishly, even as they were enacting measures that were sure to curtail it. For example, the Republican Party's Contract with America contains language extolling American values while laying out a blueprint for reducing support for many of the services working and middle class people need to get ahead in America. ${ }^{191}$ Fourth of July speeches, Presidential addresses, and preambles to significant pieces of social legislation do the same thing. For example, the campaign to abolish the estate tax featured appeals to middle income Americans and minorities based on the spurious claim that the tax discouraged private enterprise and wealth-accumulation for folks like them. ${ }^{192}$

When, a few years earlier, the Clinton administration acted to "end welfare as we know it," bipartisan supporters hailed the Personal Responsibility Act (the Welfare Reform Act of 1996) as a measure to strengthen individual initiative and encourage the idle poor to find work. ${ }^{193}$ In short, the administration touted a measure that made it more difficult for single mothers to obtain emergency food and medical services and stay in school as a means of getting them on their feet and into the job market. This reform's early years seem to have brought few of the promised gains - indeed, measured in terms of new and better jobs, healthier children, and school completion, it seems to have been an unqualified failure. ${ }^{194}$ These two programs (abolition of the estate tax and welfare reform) are illustrative of developments across the board. Even while reducing progressive taxation and

191. See Republican Party, The Contract with America, available at http://www.house.gov/?contract/ CONTRACT.html.

192. See supra Part IIA.

193. 42 U.S.C. $\S 601$ (2005). See The White House, Remarks by President Clinton at Signing of Personal Responsibility Act, M2 Presswire (online), Aug. 23, 1996.

194. E.g., Edelman, Race Meets Class, supra note 17. See also http://www.foodfirst.org/?welfare .factsheet (last visited May 31, 2006). 
funding for vital social programs, think-tank conservatives and public officials have steadfastly maintained that what they were doing was necessary to spur the economy and help people lift themselves by their bootstraps. ${ }^{195}$

\section{B. The Role of the Courts}

The public speeches, private letters, and memoranda of judges, particularly Supreme Court justices, are full of praise for the free enterprise system and our wide-open society. For example, Justice Clarence Thomas, in a speech to the Federalist Society, rhapsodized at the way our political system allows anyone with ambition and drive to get ahead: "Success (as well as failure) is the result of one's own talents, morals, decisions, and actions," he said. "Accepting personal responsibility for victory as well as for defeat is as liberating and empowering as it is unpopular today." 196

And in an essay for the Cato Institute, Justice Antonin Scalia commended our system's historic openness and lamented that we have entered into "an age in which many . . . believe that John D. Rockefeller, for all his piety . . is likely to be damned and Che Guevara, for all his nonbelief, is likely to be among the elect."197

Many of the Justices appear to think of their own careers as proof of the reality of upward mobility, ignoring that most of them were successful lawyers before ascending to the bench, and when confirmed to the Supreme Court were simply following a natural course greased by political connections and family influence. Many have been wealthy graduates of top schools. Yet, their memoirs show that many of them think that their career paths illustrate a Horatio Alger rags-to-riches story of obstacles overcome. ${ }^{198}$ Perhaps this is why the Court generally denies any obligation on the part of government to provide welfare, education, and housing services, while adamantly insisting that the lack of them should make little difference.

In Lindsey v. Normet,${ }^{199}$ for example, the Supreme Court in 1972 found that despite "the importance of decent, safe, and sanitary housing . . . the

195. See, e.g., Manuel Gonzalez \& Richard Delgado, The Politics of Fear: Republican AsCENDANCY IN AMERICA (forthcoming 2006).

196. Address Before the Federalist Society, Sept. 22, 1995 (available online at www.courttv.com/?archive/legaldocs/rights/thomas.html).

197. Economic Affairs as Human Affairs, 4 CAто J. 703, 709 (1985).

198. Justice William Douglas, for example, wrote that his mother knew poverty in "the Middle Eastern, African, and Latin-American sense of the word." William O. Douglas, Go East Young Man 8 (1974).

199. 405 U.S. 56 (1972). 
Constitution does not provide judicial remedies for every social and economic ill." ${ }^{200}$ In holding that Oregon was not obliged to provide housing for the indigent, the Court wrote: "We are unable to perceive in [the Constitution] any ... guarantee of access to dwellings of a particular quality." ${ }^{201}$ The Court was apparently untroubled by the difficulty of achieving social mobility for a person relegated to a neighborhood suffering from poor municipal services, bad schools, crime, and dilapidated housing. Indeed, in a dissenting opinion, Justice William Douglas, perhaps noticing overtones in the opinion of Marie Antoinette's famous remark that sparked the French Revolution, wrote that the Court's "approach was appropriate in the feudal culture in which property law evolved" 202 but was poorly fitted to today's climate and needs.

Only one year later, the ostensibly moderate Burger Court considered whether the Equal Protection Clause required Texas to fund public education on an equal basis. The state had been raising revenues for school districts by a scheme that relied, in part, on local property taxes so that schools in property-rich districts were able to spend considerably more per pupil than ones in districts with fewer taxable resources. In San Antonio Independent School District v. Rodriguez, ${ }^{203}$ the Court held that wealth is not a suspect class, nor education a fundamental interest. ${ }^{204}$ Thus, the Constitution, which does not require absolute equality or precisely equal services, did not compel Texas to fund its schools even-handedly. If any reform of Texas's school finance scheme were to come, the Court declared, it would have to come from the legislature, not the courts. ${ }^{205}$

A dissenting opinion by Justice Marshall took the Court to task for making a mockery of the nation's commitment to equal educational opportunity and for willfully ignoring the vital function it serves in enabling upward mobility. He wrote: "In my judgment, the right of every American to an equal start in life . . . is far too vital to permit state discrimination on grounds so tenuous as those presented by this record."206

Earlier sections of this Review Essay teach that Justice Marshall was right and that without adequately funded schools and competent teachers, the children of immigrants, minorities, and the poor will have little chance of

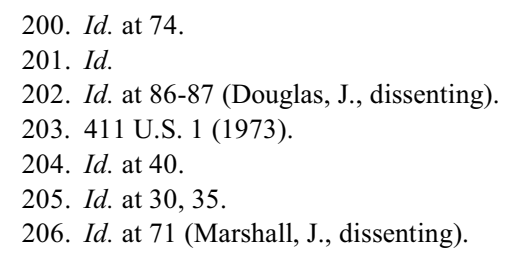


becoming the next generation of Supreme Court Justices, or, indeed, of qualifying for any high level job at all. ${ }^{207}$

Earlier, in Dandridge v. Williams, ${ }^{208}$ the Court had found that state discretion over the disbursement of welfare (in this case, Aid to Families with Dependent Children) and the resulting disparities among states and regions did not contravene the Bill of Rights nor the Fourteenth Amendment. ${ }^{209}$ Maryland had set a cap on the amount of AFDC money a family could receive regardless of its size so that large families suffered a penalty, namely less money per child for such basic necessities as food and shelter. ${ }^{210}$ While the Court recognized that welfare was one of the most basic needs of impoverished human beings, economic and social policies receive little protection from the United States Constitution. Accordingly, the Court would not impose upon the states its own view of how a welfare system should operate. ${ }^{211}$ Like the two previously mentioned cases, Dandridge can be seen as refusing to endow wealth with suspect-class status or to recognize the poor as a protected class. $^{212}$

In each of these cases, the Court characterized social and economic ills as matters for legislative, not judicial treatment. But the hope that Congress, at least, would enact effective reforms in these areas has been vain. That body cut back on welfare in the Welfare Reform Act of $1996,{ }^{213}$ and when it turned to educational reform in the No Child Left Behind Act, ${ }^{214}$ it provided for highstakes testing, and few new resources for troubled schools.

At the same time, federal and state lawmakers have been narrowing the few existing avenues of upward mobility by weakening remedies for workplace discrimination, ${ }^{215}$ tolerating a glass ceiling that limits the upward mobility of women, ${ }^{216}$ and reducing the ability of individuals to secure the protections of bankruptcy at a time when the media encourage a culture of

207. See, e.g., text and notes 134-35, 145-56, supra.

208. 397 U.S. 471 (1970).

209. Id. at 484 .

210. Id. at 473-75.

211. Id. at $485-86$.

212. $I d$.

213. U.S.C.A. $\S 1601-96$.

214. U.S.C.A. $\$ \S 6301-7941$.

215. E.g., Pat K. Chew \& Robert E. Kelley, Unwrapping Racial Harassment Law, 27 Berkeley J. EMP. \& LAB. L. 49 (2006).

216. On the glass ceiling see, e.g., Stephen J. McNamee \& Robert K. Miller, Jr., The Meritocracy Myth 169-71 (2004); U.S. Glass Ceiling Commission, A Solid Investment: Making Full Use of the Nation's Human Capital (Final Rep. of the Comm. 1995), available at http://digitalcommons .ilr.cornell.edu/key_workplace/120. 
consumption that insures that more of them will find themselves in over their heads. ${ }^{217}$

Current ads tout $\$ 130,000$ Hummers and $\$ 600$ jeans. A New York Times poll showed that fully 81 percent of Americans felt social pressure to buy high-priced goods, whether they could afford them or not. ${ }^{218}$ While some luxury goods, such as cell phones, have become more affordable over time, the super-rich continue expanding the boundaries of desire to include personal services such as chef, personal trainer, and nanny, and exotic vacations such as space tourism and exclusive summer camps for their children. ${ }^{219}$ This has led, in turn, to a "vertical desire" in which ordinary people covet the goods of the rich and powerful as seen on TV. ${ }^{220}$ Many splurge on expensive goods they cannot afford because of the availability of easy-but highpriced - credit. According to the Federal Reserve Board, Americans now owe $\$ 750$ billion in revolving debt, a six-fold increase from two decades ago. ${ }^{221}$

Living beyond one's means can give the impression that one lives in a classless society - no matter how lowly one's job, no matter that one has no idea how to finance one's children's college education, one can own some of the things that rich people do. One can easily begin to equate ownership of a few luxury items with power over one's fate, when in fact the opposite is true - the more one owns, the less autonomy one enjoys and the greater the chance that one will one day meet a stone wall. ${ }^{222}$ Many Americans believe that they live in the best and freest society on earth. But when asked what that means, many say that they can shop at a range of stores for a variety of goods. ${ }^{223}$ Few mean voting, free speech, or a realistic chance to rise to a decision making position in society, for oneself or one's children. ${ }^{224}$

217. See text and notes $14,25-28$, supra, 218-20 infra (describing "vertical aspiration").

218. See Jennifer Steinhauser, When the Joneses Wear Jeans: Signs of Status are Harder to Spot, N.Y. Times, May 29, 2005, at 12-13 [hereinafter Steinhauser, Wear Jeans].

219. Id.

220. Id. See also note 14 supra (describing how "lifestyle" aspiration and consumption are replacing the hard-work variety). See also MTV's popular "MTV Cribs," in which hip hop artists, athletes, and other celebrities show off their multi-million dollar homes, stable of luxury cars, and other expensive possessions.

221. Steinhauser, Wear Jeans, supra note 218, at 12-13. See also Steinhauser, Wear Jeans, supra note 218 , at 13 .

222. Id. at $12-13$

223. See Andrew Hacker, Money: Who Has How Much and Why 41 (1997).

224. See 20 Nation Poll Finds Strong Global Consensus: Support for Free Market System, But Also More Regulation of Large Companies, http://www.worldpublicopinion.org/pipa/?articles/ btglobalizationtradera/154.php?nid=\&id=\&pnt=154 (last visited June 7, 2006). 


\section{Conclusion: Needed-A Better Myth}

Joseph Campbell and others have argued that a society's myths say much about it and are important ways it organizes its business. ${ }^{225}$ With upward mobility, society needs a better myth. The current one is dysfunctional - individualistic, unrealistic, and prone to promise more than it can deliver. Descriptively, or even aspirationally, it lacks any mooring in our current circumstances.

American society, and especially ordinary workers, would do better to substitute a new narrative - that of working-class solidarity-for the current version that does such mischief. An emphasis on working class solidarity would assure steady group progress and would include such aims as better education, stronger unions, better occupational health and safety requirements, a higher minimum wage, and a safety net of services, including health care, for those who need them. It would seek changes that would benefit everyone, substituting genuine progress for mythical dreams or misnamed TV shows that do not depict reality at all.

It would capture the teaching of Graetz and Shapiro that dreams do not happen merely because we desire them, but require work, vigilance, and resistance to false rhetoric. The new myth would reject simplistic remedies such as Murray's flat-grant solution, substituting programs that rekindle hope, inspire community, and do not dissipate our national treasure in trivial ways that have little chance of making a lasting contribution to the fair and just society that we aspire to be. 